\title{
Repeated exposure to acid and bile selectively induces colonic phenotype expression in a heterogeneous Barrett's epithelial cell line
}

\author{
Manisha Bajpai ${ }^{1}$, Jianying Liu ${ }^{1}$, Xin Geng ${ }^{1}$, Rhonda F Souza ${ }^{2}$, Peter S Amenta ${ }^{3}$ and Kiron M Das ${ }^{1}$
}

Barrett's epithelium is a precancerous, specialized columnar metaplasia in the distal esophagus. We demonstrate the changes in cellular phenotype in a non-neoplastic Barrett's cell line (BAR-T), following exposure to acid and bile salt, the two important components of gastroesophageal refluxate. Cell phenotypes in BAR-T cell line were quantified by fluorescence-activated cell sorting (FACS) using monoclonal antibodies against markers: cytokeratin 8/18 (CK8/18) for columnar, CK4 for squamous, mAbDas-1 for colonic epithelial cell phenotype and p75NTR for esophageal progenitors. Cells were exposed for 5 min each day to $200 \mu \mathrm{M}$ glycochenodeoxycholic acid at pH 4, pH 6 and pH 7.4 or only to acid $(\mathrm{pH} 4)$ for up to 6 weeks. The BAR-T cell line comprised $35 \pm 5.2 \%$ CK8/18, $32 \pm 3.5 \%$ mAbDas $-1,9.5 \pm 3 \%$ CK4 and $4 \pm 2.5 \%$ p75NTR-positive cells. Single exposure to acid and or bile did not change cell phenotypes. However, chronic treatment for at least 2 weeks significantly enhanced $(P<0.05)$ the expression of colonic phenotype and CK8/18-positive cells, as evidenced by FACS analysis. Bile salt at $\mathrm{pH} 4$ and bile salt followed by acid $(\mathrm{pH} 4)$ in succession were the strongest stimulators $(P<0.01)$ for induction of colonic phenotype cells. Squamous $\left(\mathrm{CK}^{+}\right)$phenotype did not change by the treatments. Cox-2 expression was induced after acute treatment and increased to twofold during chronic treatment, particularly in response to acidic pH. We conclude that BAR-T cells can be utilized as an 'in vitro' model to study the effect of environmental factors and their influence on the cellular phenotype and molecular changes in the pathogenesis of esophageal cancer.

Laboratory Investigation (2008) 88, 643-651; doi:10.1038/labinvest.2008.34; published online 21 April 2008

KEYWORDS: mAbDas-1; Cox-2; CK8/18; gastroesophageal reflux; Barrett's cell line; cell phenotype

Barrett's epithelium (BE) is an acquired metaplastic change at the squamocolumnar junction of the distal esophagus secondary to chronic gastroesophageal reflux disease (GERD). ${ }^{1-3}$ Epidemiological studies indicate a strong relationship between GERD and esophageal adenocarcinoma, ${ }^{4-7}$ with the risk of malignant transformation being 30 - to 125 -fold higher in GERD patients complicated with BE. ${ }^{8,9}$ The origin and pathological progression of $\mathrm{BE}$ and the contribution of gastroesophageal reflux in the disease process have been extensively studied in animal models. ${ }^{1,10-13}$ The metaplastic process of $\mathrm{BE}$ appears to be a protective adaptation ${ }^{14}$ or a regenerative healing mechanism. ${ }^{15}$ It is hypothesized that 'pleuripotent cells' from the native esophageal stratified squamous epi- thelium or ductal epithelium of the esophageal submucosal glands may give rise to the specialized columnar epithelium. ${ }^{16,17}$ However, this can be further established by delineating the cellular phenotype and molecular events involved in the metaplasia $\rightarrow$ dysplasia $\rightarrow$ carcinoma sequence. $^{18}$

Acid and bile, the two primary components of gastroesophageal refluxate, act synergistically in inducing mucosal injury. ${ }^{19}$ Molecular events resulting from GERD in humans have been studied in esophageal biopsies and adenocarcinoma cell lines. A single pulse of either bile or acid independently increases cell survival and proliferation, as well as decreases apoptosis, perhaps by inducing Cox-2 expression, via the MAPKinase ${ }^{20-23}$ and ERK pathway. ${ }^{24}$ Both acid

\footnotetext{
${ }^{1}$ Division of Gastroenterology and Hepatology, Department of Medicine, UMDNJ-Robert Wood Johnson Medical School, New Brunswick, NJ, USA; ${ }^{2}$ Division of Gastroenterology, Departments of Medicine, Dallas VA Medical Centre and the University Of Texas Southwestern Medical School, the Harold C Simmons Comprehensive Cancer Centre, University of Texas of Southwestern Medical Centre at Dallas, Dallas, TX, USA and ${ }^{3}$ Division of Pathology, Department of Medicine, UMDNJRobert Wood Johnson Medical School, New Brunswick, NJ, USA

Correspondence: Dr KM Das, MD, PhD, Division of Gastroenterology and Hepatology, The Crohn's and Colitis Center of New Jersey, UMDNJ-Robert Wood Johnson Medical School, 1 Robert Wood Johnson Place, MEB 478, New Brunswick, NJ 08901, USA. 
and bile have been proposed to promote intestinal-type differentiation in esophageal keratinocytes by inducing the transcription factors NF- $\kappa \mathrm{B}$ and $\mathrm{Cdx}-2 .{ }^{25,26}$ Acid has been shown to induce villin expression in normal esophageal biopsy tissues grown in organ culture ${ }^{27}$ and bile, at neutral $\mathrm{pH}$, to cause DNA damage in esophageal cell lines. ${ }^{28}$ In all of these experiments, acid and/or bile exposure have been only short-term for few minutes or hours primarily using cancer cell lines and organ cultures. There are, however, no reports of cellular phenotype or molecular changes resulting from long-term (weeks) exposure to acid and bile as in the in vivo situation in patients with GERD.

We developed, in our laboratory, a colonic epithelial-specific antibody, mAbDas-1 (also called 7E12H12, IgM isotype), that reacts only with the colon epithelium and not with any other part of the gastrointestinal tract, including columnar epithelium of small intestine, stomach and the squamous epithelium of the esophagus. ${ }^{29,30}$ The reactivity is more intense near the cell membrane. mAbDas-1 reacts with a glycoprotein, termed colon epithelial protein (CEP), that is selectively expressed in the colon epithelium. ${ }^{31}$ Although it does not react with normal esophagus, including gastroesophageal junction mucosa, mAbDas-1 can identify BE as well as adenocarcinoma arising from BE with $97 \%$ sensitivity and $100 \%$ specificity, suggesting that BE is indeed a metaplasia of colonic phenotype. ${ }^{32}$ This has been confirmed by several independent studies. ${ }^{33-39}$ Furthermore, mAbDas-1 can detect colonic metaplasia before the histological appearance of BE, suggesting the existence of a 'Pre-Barrett's' stage $^{34,35}$ The data suggest that expression of CEP preceded histological $\mathrm{BE}$ and persisted during development of metaplasia and progression to carcinoma.

Cox-2 has been implicated in the neoplastic progression in Barrett's esophagus. ${ }^{2,24,40}$ Increased levels of Cox-2 have been reported in Barrett's tissues ${ }^{41}$ and in several cases of esophageal adenocarcinoma, ${ }^{22,40,42-44}$ although no causal link has yet been established. Cox-2 expression is generally associated with inflammatory or stress responses. ${ }^{45}$ Cox- 2 overexpression is linked with inhibition of apoptosis, increased invasiveness of malignant tumors and enhanced synthesis of tissue prostaglandins ${ }^{46-49}$ in gastrointestinal cancers.

Cytokeratin 8/18 (CK8/18), a marker of columnar epithelium, is not expressed by the squamous epithelium of the esophagus. Overexpression of CK8/18 protein has been reported in some adenocarcinomas, ${ }^{50}$ but its expression in esophageal adenocarcinoma is unknown. CK8/18 has been observed in multi-layered epithelium in $\mathrm{BE}$ by immunocytochemistry. ${ }^{51}$ This focal multi-layered epithelium within BE comprises cells that concurrently express both squamous and columnar cytokeratin markers, much like the esophageal mucosal gland duct epithelium ${ }^{34}$ and the non-neoplastic telomerase-immortalized Barrett's cell line, $(\mathrm{BAR}-\mathrm{T}) .^{52}$

We utilized the BAR-T cell line as a model to identify the specific cell phenotype in a heterogeneous ${ }^{52}$ cell population that could demonstrate molecular and/or cell phenotypic changes following chronic exposure to acid and bile. We utilized specific cell-phenotype markers: CK8/18 for columnar, CK4 for squamous, mAbDas-1 for colonic phenotype and p75NTR suggested as marker for esophageal progenitors $^{53,54}$ and quantified the cells displaying each phenotype. We compared the expression of all of these markers sequentially in the BAR-T cells, following a single 5-min exposure (acute exposure) to acid ( $\mathrm{pH} 4)$ or bile at $\mathrm{pH}$ 7.4, or bile at $\mathrm{pH} \mathrm{4,} \mathrm{and} \mathrm{then} \mathrm{continued} \mathrm{similar} \mathrm{exposure,}$ every day, for up to 6 weeks (chronic exposure). Cox-2 protein expression was monitored in parallel as an indicator for cellular response to external stress induced by acid and bile salt treatment.

\section{MATERIALS AND METHODS Cell Line, Media and Cell Culture}

BAR-T cells were grown in special supplemented keratinocyte medium (KBM2) from Cambrex Bioscience (East Rutherford, NJ, USA), as per the protocol described by Jaiswal et al. ${ }^{20}$ Hydrochloric acid was used to adjust the $\mathrm{pH}$ of the culture medium to experimental conditions. The bile acid, glycochenodeoxycholic acid, GCDA (Sigma, St Louis, MI, USA), was diluted to optimum working concentration of $200 \mu \mathrm{M}^{20}$ with the culture medium adjusted to either $\mathrm{pH} 4$ (bile pH 4), pH 6 (bile pH 6) or pH 7.4 (bile) immediately before being added to the cell culture. For acute exposure, $0.1 \times 10^{6}$ cells growing on six-well plates were incubated in acid and/or bile for $5 \mathrm{~min}$ in $24 \mathrm{~h}$. For chronic exposure, cells were exposed for $5 \mathrm{~min}$ everyday, for up to 6 weeks. No treatment was done on the day the cells were passed. The time was optimized from similar studies, showing that $5 \mathrm{~min}$ was sufficient for induction of signal transduction pathways regulating cellular machinery without cell damage. ${ }^{22-24}$ The cells were rinsed with phosphate buffered saline (PBS) before and after incubation with desired treatment medium. The control untreated cells were grown in parallel in the special medium as mentioned above at $\mathrm{pH}$ 7.4. To examine the possible priming effect of acid or bile in possible combinations, we investigated acid treatment followed by bile $(A \rightarrow B)$, bile followed by acid $(B \rightarrow A)$ or acid followed by acid $(\mathrm{A} \rightarrow \mathrm{A})$, with a PBS wash between treatments. The cells were replenished with culture medium and allowed to grow in the incubator at $37^{\circ} \mathrm{C}$ and $5 \% \mathrm{CO}_{2}$ for the duration of the experiment.

\section{Antibodies}

The primary antibodies used were mouse monoclonal antibody, mAbDas-1 (IgM isotype), developed in our laboratory against a human colonic epithelial protein, CEP. ${ }^{29,31}$ The Cox-2 monoclonal antibody (IgG isotype) was obtained from Cayman Chemicals (Ann Arbor, MI, USA). Monoclonal antibodies against CK8/18 (IgG clone M20) and CK4 (IgG) were obtained from Abcam (Cambridge, MA, USA), and p75NTR antibody (IgG) was obtained from Novus Biologicals 
(Littleton, CO, USA). Anti-actin IgG (clone AC-40) was obtained from Sigma. Isotype-specific murine IgM, IgG (MOPC-IgM and IgG), biotinylated rabbit anti-mouse IgM and streptavidin peroxidase kit were obtained from Dako Corp. (Carpinteria, CA, USA). Carbocyanine fluorophore 2-conjugated goat anti-mouse $\operatorname{IgG}$ and phycoerythrin (PE)-conjugated goat anti-mouse IgM (secondary antibodies) were obtained from Jackson Immunologicals (Westgrove, PA, USA). PE-IgM for mAbDas-1 and CY2-IgG for CK8/18 were used for colocalization experiments. Immunogold $(10 \mathrm{~nm})$-labeled secondary IgM was obtained from Electronmicroscopy Sciences (Fort Washington, PA, USA).

\section{Fluorescence-Activated Cell Sorting}

Fluorescence-activated cell sorting (FACS) was used to quantitate the number of cells expressing various marker proteins. Cells were fixed and permeated with Cytofix/Cytoperm reagent (BD Biosciences, Pharmingen, San Diego, CA, USA) for $20 \mathrm{~min}$ at $4^{\circ} \mathrm{C}$. After fixation, cells were washed twice with PBS. Approximately $0.5 \times 10^{6}$ cells in reaction buffer $(1 \%$ goat serum, $2 \mathrm{mM}$ EDTA in PBS) were incubated for $1 \mathrm{~h}$, or overnight, at $4^{\circ} \mathrm{C}$ with primary antibodies. The cells were rinsed twice with 30 volumes of FACS wash buffer $(0.5 \%$ BSA, $2 \mathrm{mM}$ EDTA and $0.005 \%$ NaN3 in PBS) and incubated with corresponding fluorescence-labeled secondary antibodies for $45 \mathrm{~min}$ at room temperature. After the final rinse, cells were examined in the Cytomics FC500 cytometer. As the cells were stained with varying intensity and there was no distinct sharp peak, the number of positive cells was calculated using the Overton method of cumulative histogram subtraction. ${ }^{55}$

\section{Immunocytochemical Localization of CEP in BAR-T Cells}

(a) Immunoperoxidase staining: For immunostaining, cytospin preparation of BAR-T cells was fixed and stained using the method previously described. ${ }^{29,32}$ Briefly, the cells were incubated with 1:20 dilution of mAbDas-1 overnight at $4{ }^{\circ} \mathrm{C}$ followed by biotin-conjugated rabbit anti-mouse secondary IgM (1:50) for $1 \mathrm{~h}$, with avidinbiotin enzyme reagent for $30 \mathrm{~min}$ and finally with peroxidase substrate for color development.

(b) Immunofluorescence staining: Indirect immunostaining of BAR-T cell cytospins was performed using the same reagents and method as mentioned under FACS assay. Stained slides were viewed under a Zeiss fluorescence microscope at $\times 20$ with appropriate filters.

(c) Electron microscopy: More precise localization of the CEP was performed by electron microscopy (EM) using the immunogold labeling technique. Biopsy tissue from a patient with BE was fixed and embedded in histogel (for preparing 5- to $6-\mu \mathrm{m}$ sections). Tissue sections were incubated with mAbDas-1 (1:20) overnight and subsequently with immunogold-labeled secondary antibody (1:5) overnight. After this, tissue was prepared following standard procedure for EM.

\section{Western Blot}

Total protein from BAR-T and colon cancer cells LS180 was obtained as follows. Cells were homogenized in lysis buffer (200 mM HEPES, $5 \mathrm{mM} \mathrm{KCl}, 0.5 \mathrm{mM} \mathrm{MgCl}$, EDTA $0.1 \mathrm{mM}$, SDS $0.1 \%$ and protease inhibitor cocktail (Sigma)), centrifuged and the supernatant was collected. The total amount of protein was quantitated and $10 \mu \mathrm{g}$ of total protein was resolved in 10\% SDS-PAGE gel electrophoresis. ${ }^{31,56}$ After transferring the proteins to the nitrocellulose membrane overnight, the blots were blocked in $1 \%$ low-fat milk and then incubated with primary antibody mAbDas- 1 overnight at $4^{\circ} \mathrm{C}$. The membrane was incubated with biotinylated secondary antibody for $1 \mathrm{~h}$ and the chemiluminescence reaction (Perkin Elmer Chemiluminescence kit) was performed following the manufacturer's protocol. Autoradiographs were developed after 5-15 min. The same blots were also incubated with anti-actin antibody as protein loading control.

\section{Proliferation Assay}

The proliferation of the cells was measured using 5-bromo 2 deoxyuridine (BrdU) incorporation-based colorimetric assay (Roche Diagnostics, Indianapolis, IN, USA). Approximately $0.1 \times 10^{4}$ cells from each group were plated in a 96 well plate in triplicate; after acid and/or bile salt treatment for $24 \mathrm{~h}, \mathrm{BrdU}$ was added for $2 \mathrm{~h}$. Thereafter, the cells were fixed for $30 \mathrm{~min}$ at $15-25^{\circ} \mathrm{C}, 100 \mu \mathrm{l}$ anti-BrDU POD-conjugated antibody (diluted 1:100) was added per well and incubated for $90 \mathrm{~min}$ in the dark, at room temperature. After rinsing the wells three times with wash buffer, $100 \mu \mathrm{l}$ substrate solution was added per well and incubated at $15-25^{\circ} \mathrm{C}$ for $5-30 \mathrm{~min}$. Absorbance was read on a Molecular Devices kinetic microplate reader at $450 \mathrm{~nm}$.

\section{Statistical Analysis}

GraphPad Instat3 software (San Diego, CA, USA) was used for all statistical analyses. Analysis of variance was followed by Tukey's multiple comparisons test to determine the significance of the data obtained, represented by ${ }^{\star}(P<0.05)$ or ${ }^{* *}(P<0.01)$ for comparisons between untreated control and experimental or treated groups and ${ }^{\S}(P<0.05)$ for comparisons between only acid- or only bile-treated and other combination treatment groups. The bars indicate \pm s.e.m.

\section{RESULTS}

Telomerase-Immortalized Benign Barrett's Cell Line is a Heterogeneous Mix of Cells Expressing Columnar, Colonic and Squamous Epithelial Cell Phenotypes

CK8/18 and mAbDas-1 staining was observed at low intensity in the majority of the cells. Following quantification from at least six experiments, ${ }^{55}$ it was observed that approximately $32 \pm 3.5 \%$ of the BAR-T cells were of colonic phenotype (mAbDas-1 positive) and $35 \pm 5.2 \%$ expressed columnar marker CK8/18. Only $9.5 \pm 3 \%$ of the cells were positive for squamous cell marker CK4, and a very small population of cells $(4 \pm 2.5 \%)$, stained for p75NTR, which has been reported 
a (i)

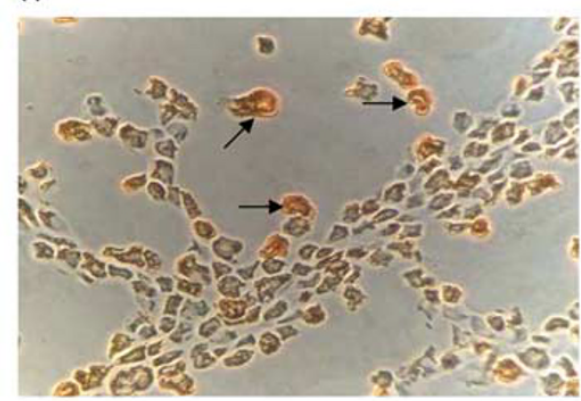

$\mathrm{mAb}$ Das-1 peroxidase staining (ii)

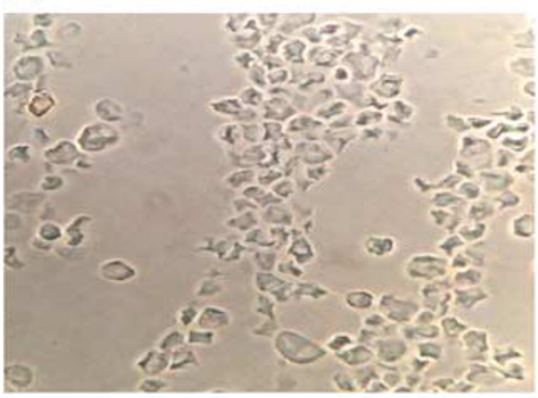

MOPC IgM control b

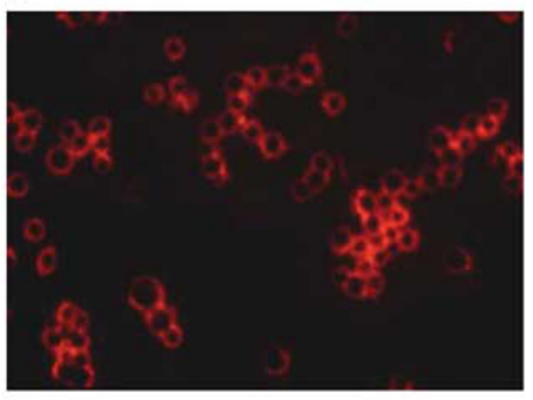

mAb Das-1 fluorescence staining

Immunostaining of Bar-T cells

C

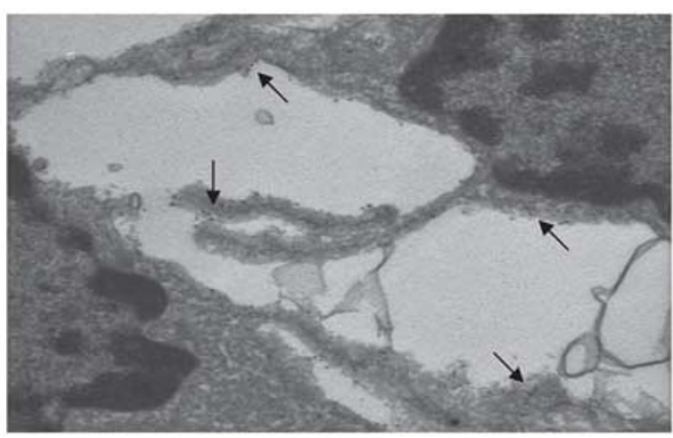

Immunogold localization of CEP in Barrett's epithelial tissue by $\mathrm{EM}$ d

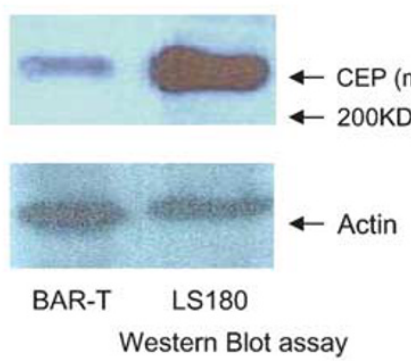

Figure 1 Immunostaining of Bar-T cells. (a) (i) mAbDas-1 peroxidase staining. (ii) MOPC IgM control. (b) mAbDas-1 fluorescence staining. (c) Immunogold localization of CEP in Barrett's epithelial tissue by EM. (d) Western blot analysis of BAR-T cells and LS180 colon cancer cells.

as an esophageal progenitor cell marker. ${ }^{53,54}$ Immunoperoxidase staining of mAbDas-1 (Figure 1ai) showed weak diffuse staining of cytoplasm with increased staining on the periphery of the cells, which is more evident by immunofluorescence assay (Figure 1b). Figure 1aii shows mouse IgM isotype control for immunoperoxidase assay. Immunogold localization of mAbDas- 1 reactivity by electron microscope in BE biopsy tissue (Figure 1c) further confirmed enhanced expression of CEP toward the cell membrane. Western blot analysis of cell lysate from BAR-T cells and colon cancer cells LS180 (as a positive control) showed a distinct high molecular-weight protein (CEP) $>200 \mathrm{kDa}$ (Figure 1d). The colon cells where CEP was originally identified have much higher expression of the protein than the BAR-T cells.

Double-color FACS analysis showed that almost all of the mAbDas-1-positive cells were also stained for CK8/18 (Figure 2ai-iii). Figure 2aiv shows fluorescence microscope picture of double staining for coexpression of CEP and CK8/ 18. The CK4-positive cells did not stain for CEP (data not shown).

\section{Effect of Single and Repeated Exposure to Acid and Bile on the Expression of CEP and CK8/18}

Multiple exposures on the same day resulted in considerable cell death $(>80 \%)$ due to membrane disintegration, and further analysis was not performed with these cells. When the
BAR-T cells were treated daily with acid and/or bile for $5 \mathrm{~min}$ (only once a day), a gradual increase in the expression of CEP was observed after 1 week. The induction continued during the second week and reached a plateau by the third week, which persisted for up to 6 weeks (the maximum duration of the experiments). After 2 weeks of treatment, acid alone induced CEP expression to 1.55 -fold $(P<0.05)$, and bile at $\mathrm{pH}$ 7.4 as well as at $\mathrm{pH} 6$ to 1.4 -fold $(P<0.05)$ when compared to untreated cells of the same duration. Treatment with bile at $\mathrm{pH} 4$, however, caused a 2.1 -fold $(P<0.01)$ increase in CEPpositive cells when compared with untreated cells growing for 2 weeks (Figure 3). The increased expression of CEP as observed by FACS (Overton method) is shown in Figure $2 \mathrm{~b}$ (lower panel).

Cells treated with bile at $\mathrm{pH} 4$ also showed induction of CK8/18 protein expression, up to 1.62 -fold $(P<0.01)$ at 2 weeks (Table 1). The acid only-treated group expressed a 1.37 -fold $(P<0.05)$ higher $\mathrm{CK} 8 / 18$ protein in 2 weeks compared to the untreated cells, and bile $\mathrm{pH} 7.4$ did not change the expression of CK8/18. Quantification of cells for single protein expression, either CEP or CK8/18, as well as coexpression of both CEP and CK8/18 in the same cells by dualcolor protein localization FACS analysis after various treatments is shown in Table 1. Increased expression of both the proteins, CEP and CK8/18, was evident in acid $\mathrm{pH} 4$ - as well as bile $\mathrm{pH}$ 4-treated cells. 
a (i)

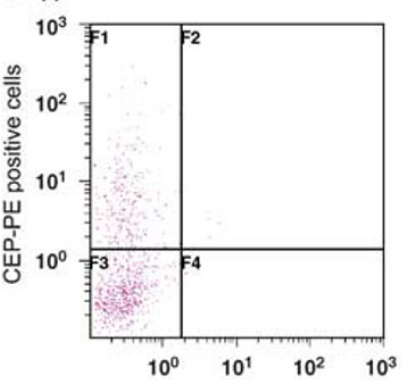

(ii)

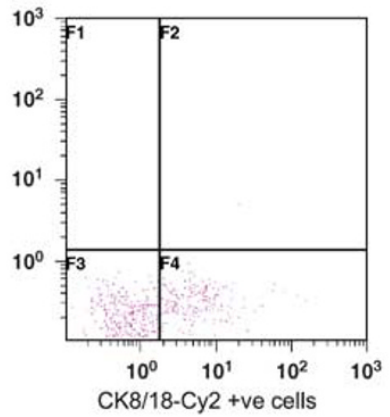

(iii)

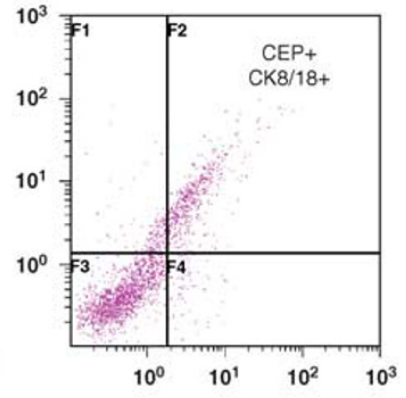

(iv)

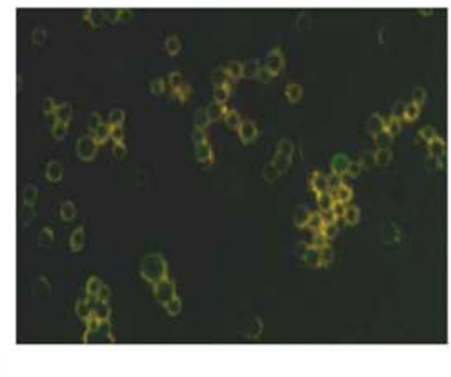

b

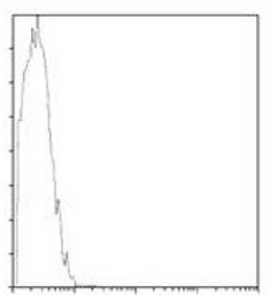

MOPC IgG control

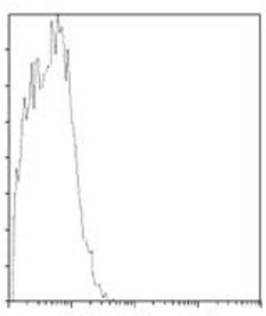

MOPC IgM control

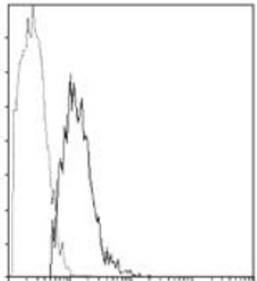

Cox-2 untreated control

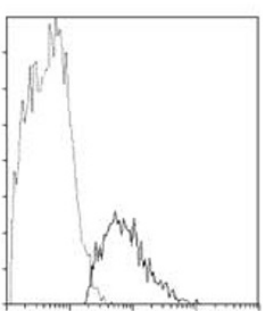

CEP untreated control

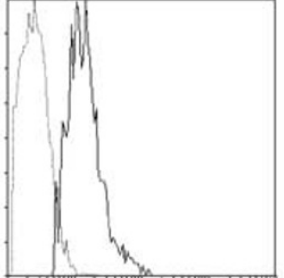

Cox-2 after acid treatment

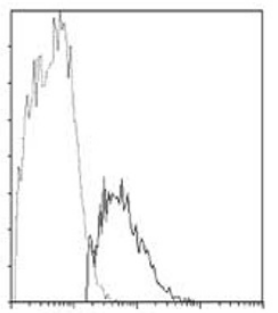

CEP after acid treatment

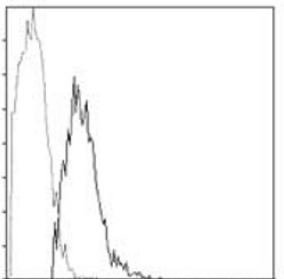

Cox-2 after bile treatment

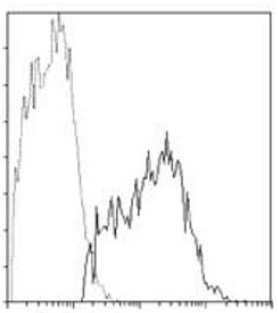

CEP after bile treatment

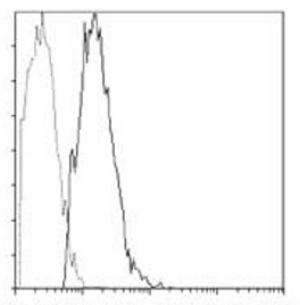

Cox -2 after acid + bile pH 4 treatment

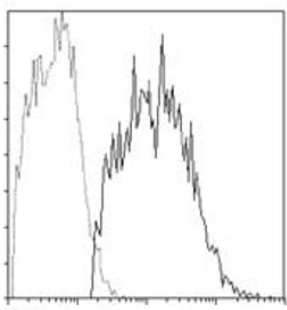

CEP after acid + bile $\mathrm{pH} 4$ treatment

Figure 2 (a) Double-color immunofluorescence assay. (b) Effect of acid and bile on the expression of Cox-2 (upper panel) and CEP (lower panel) in BAR-T cells. (i) and (ii) show single color staining for CEP and CK8/18, respectively, (iii) and (iv) show double color-colocalization by FACS analysis and immunofluorescence microscopy, respectively.

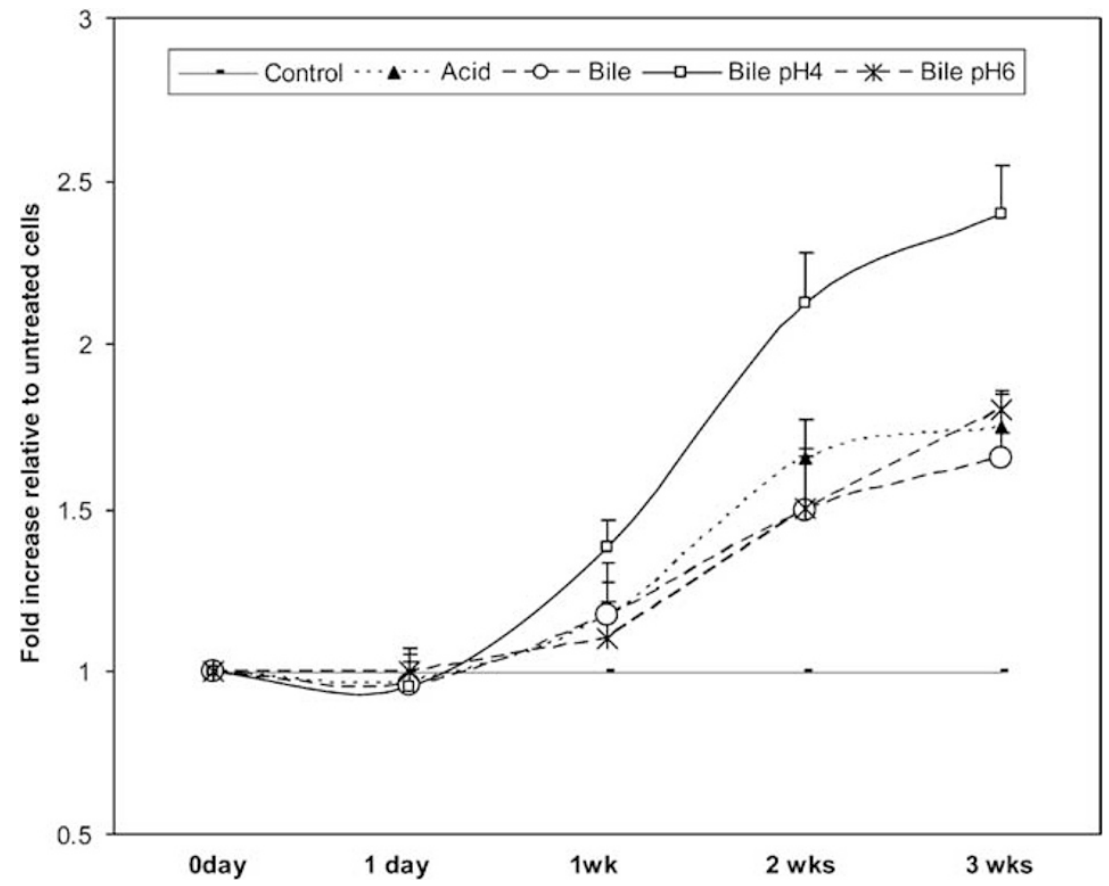

Figure 3 Effect of continued treatment of BAR-T cells with acid and bile on CEP expression. 
Table 1 Effect of acid and bile salt treatment for 2 weeks on the expression of different cell phenotypes in the BAR-T cells

\begin{tabular}{|c|c|c|c|c|c|c|c|}
\hline & CEP +ve & CK8/18+ve & CEP +ve CK8/18 +ve & Cox-2 +ve & Cox2 +ve CEP +ve & Cox-2 +ve CEP -ve & CK4 +ve \\
\hline Control & $32 \pm 3.5$ & $35.5 \pm 5.2$ & $31 \pm 1.9$ & $23 \pm 1.2$ & $12 \pm 2$ & $11.7 \pm 4.2$ & $9.5 \pm 2.96$ \\
\hline Bile pH 7.4 & $45.3 \pm 1.94^{*}$ & $40.9 \pm 4.5$ & $38.3 \pm 5.34^{*}$ & $33 \pm 5^{*}$ & $14 \pm 4$ & $15 \pm 3.2$ & $10.3 \pm 0.29$ \\
\hline Bile pH 4 & $68 \pm 5.4^{* * \S}$ & $56.7 \pm 4.1 * * \S$ & $48 \pm 0.49^{*}$ & $47 \pm 1.8^{* * \S}$ & $22 \pm 2.5^{\star}$ & $21 \pm 1.5^{\star}$ & $11.3 \pm 0.64$ \\
\hline
\end{tabular}

Table represents percent positive cells in each group \pm s.e.m. obtained from $n=6$ for single-staining and $n=3$ for double-staining FACS experiments. The different treatment conditions are shown in horizontal rows and the cell phenotypes in each group recorded in vertical columns. For coexpression analysis, anti-mouse lgM labeled with PE (for anti-mAbDas-1 IgM) and anti-lgG labeled with Cy-2 were used.

${ }^{\star} P<0.05$ or ${ }^{* *} P<0.01$ for comparisons between untreated control and experimental or treated groups and ${ }^{\S} P<0.05$ for comparisons between the treated groups by Tukey's multiple comparisons test.

These observations indicate that the cells expressing columnar and colonic phenotype markers were mostly induced in response to acid or bile salt treatment, as there was no change in the number of cells expressing CK4 protein. Both acid and bile salt treatment could individually induce changes of similar magnitude in the expression of colonic and columnar phenotype markers in BAR-T cells. However, bile salt in acidic $\mathrm{pH} 4$ was more effective when compared to either alone $\left({ }^{\S} P<0.05\right)$ (Table 1$)$.

\section{Effect of Successive Exposure to Acid or Bile Salt Treatment}

To examine the sequential effects of acid and bile salt treatment, BAR-T cells were exposed to acidic $\mathrm{pH} 4$ for $5 \mathrm{~min}$ followed by repeat exposure with same $(\mathrm{A} \rightarrow \mathrm{A})$, daily for 2 weeks, which induced CEP expression by 1.7 -fold $(P<0.05)$ compared to untreated cells. Similar treatment for 2 weeks with bile at $\mathrm{pH} 7.4$ following acid $(\mathrm{pH} 4)$ priming $(\mathrm{A} \rightarrow \mathrm{B})$ increased CEP expression 1.96-fold $(P<0.05)$, and the third group with acid $(\mathrm{pH} 4)$ treatment following bile at neutral $\mathrm{pH}$ priming $(\mathrm{B} \rightarrow \mathrm{A})$ induced $\mathrm{CEP}$ up to 2.4 -fold $(P<0.01)$ when compared to untreated control cells. $\mathrm{B} \rightarrow \mathrm{A}$ was also more significant $\left({ }^{\S} P<0.05\right)$ than either acid or bile alone in inducing CEP expression (Figure 4).

\section{Effect of Acid and Bile on Cox-2 Expression in BAR-T Cells}

Twenty-three $\pm 1.2 \%$ of the BAR-T cells were stained for Cox-2 protein expression in control untreated condition. Unlike the other proteins, Cox-2 was induced early in the first week of treatment, 1.4-fold by acid $(\mathrm{pH} 4)$ alone and 1.5 -fold by bile at $\mathrm{pH} 4$, when compared to untreated cells of the same duration. It increased further to 1.75 -fold $(P<0.05)$ by acid alone and twofold $(P<0.01)$ by bile at $\mathrm{pH} 4$ at the second week, when compared to untreated control cells. The response to bile salt treatment at $\mathrm{pH} 7.4$ as well as $\mathrm{pH} 6$ was minimal until 2 weeks when it increased to 1.54 -fold $(P<0.05)$ compared to the untreated cells (Figure 5). A representative FACS flow diagram of the increase is shown in Figure $2 \mathrm{~b}$ (upper panel). These elevated levels of Cox-2 were

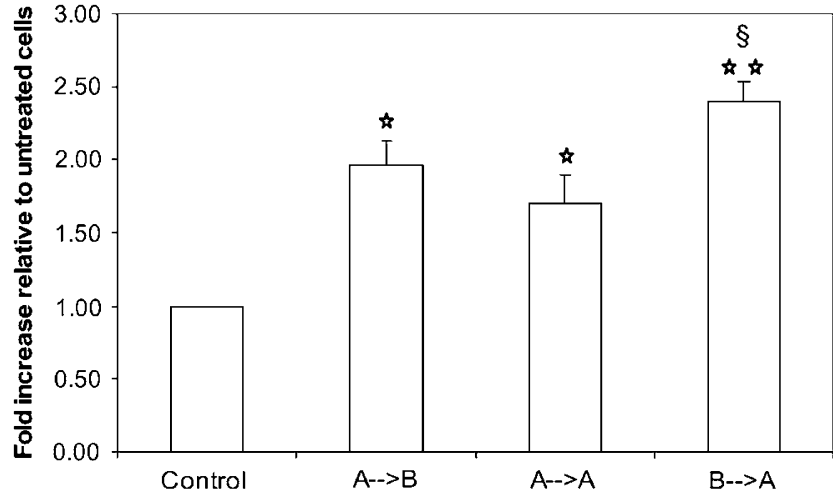

Figure 4 Effect of continued treatment of BAR-T cells for 2 weeks sequentially with acid or bile, on CEP expression. ${ }^{\star} P<0.05$ or ${ }^{\star *} P<0.01$ for comparisons between untreated control and experimental or treated groups and ${ }^{\S} P<0.05$ for comparisons between the treated groups.

maintained beyond 3 weeks with minor changes up to 6 weeks. Double-color immunofluorescence revealed that $12 \pm 2 \%$ of the total (untreated) Cox-2-positive cells were CEP- and/or CK8/18-positive. After stimulation with acid and/or bile for 2 weeks, the expression of Cox- 2 in CEP- and/ or CK8/18-expressing cells (major population of cells) was doubled. However, Cox-2 expression was also increased about 1.5 -fold in the CEP- and/CK8/18-negative cells (Table 1).

\section{Proliferation Assay}

Considering BrDU incorporation in the control untreated group to be 100 , the changes in the treated groups are acid $\mathrm{pH} 4,97 \pm 12$; bile $\mathrm{pH} 7.4,98 \pm 10$; $\mathrm{A}+\mathrm{B} \mathrm{pH} 4,90 \pm 10$; and $\mathrm{A}+\mathrm{B} \mathrm{pH} 6,105 \pm 5$. Therefore, acid and/or bile salt treatment for 2 weeks did not alter the proliferation of the BAR-T cells.

\section{DISCUSSION}

Intestinal metaplasia in the esophagus and stomach can be divided into complete or small intestinal and incomplete or colonic phenotype on the basis of enzyme assays and the 


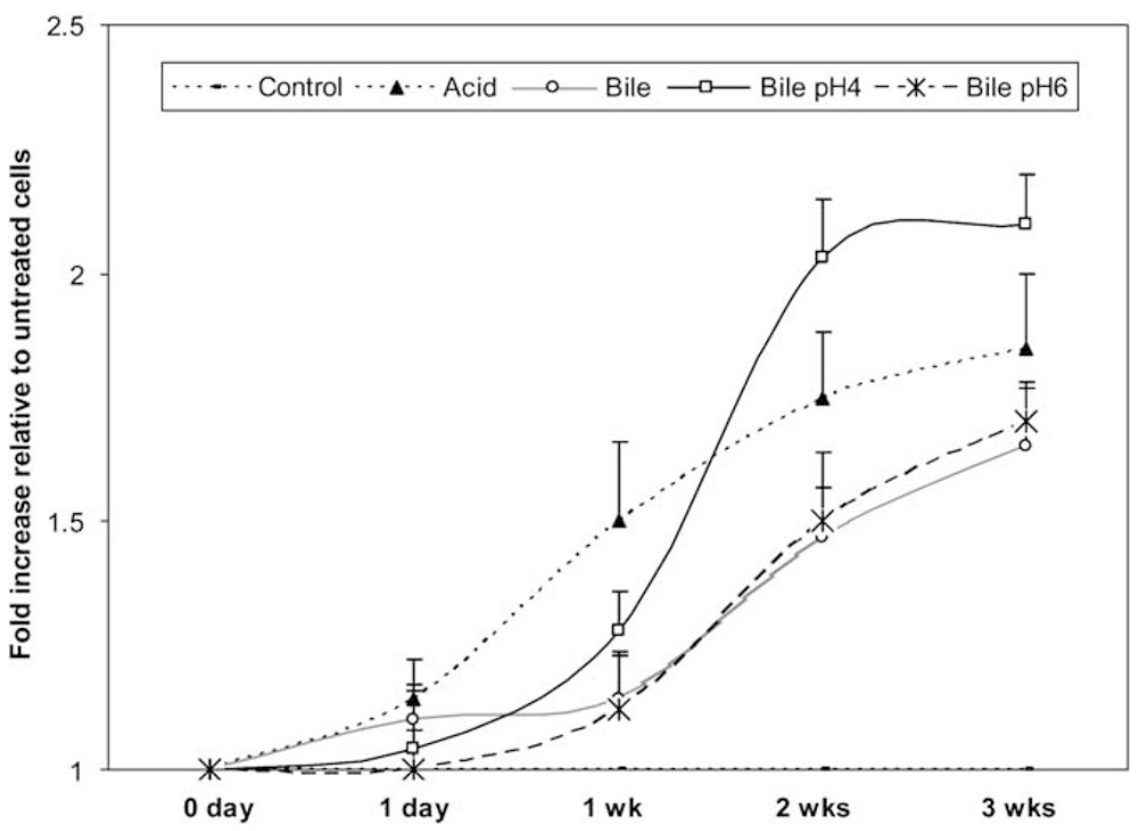

Figure 5 Effect of continued treatment of BAR-T cells with acid and bile on Cox2 expression.

difference in glycoproteins in the goblet cells. ${ }^{57-60}$ Incomplete or colonic phenotype appears to carry the highest preneoplastic potential. ${ }^{61}$ Colonic type of metaplasia as detected by mAbDas- 1 has been reported to be associated with gastric, ${ }^{62}$ small intestinal ${ }^{63}$ and also urinary bladder carcinoma. ${ }^{64,65}$ Ninety-three percentage of gastric intestinal metaplasia reactive to mAbDas-1 (colonic phenotype) was associated with gastric cancer. ${ }^{61,62}$ These findings support the potential of mAbDas-1 antibody as a preneoplastic marker for colonic phenotype of cells with malignant potential. This study demonstrates that acid and bile salt exposure, over an extended period of at least 2 weeks, can trigger progressive increase of colonic phenotype marker (mAbDas-1), in columnar type cells (CK8/18-positive) in a heterogeneous Barrett's cell line. This change in phenotype markers was not associated with any change in proliferation, although Cox-2 was significantly induced.

Both acid and bile salt were individually capable of inducing gradual increase in the number of colonic phenotype cells after continued treatment for 2 weeks. It is of interest that the most explicit induction of mAbDas-1-positive cells was seen with bile at $\mathrm{pH} 4$, and also when acid exposure followed soon after bile in neutral $\mathrm{pH}(\mathrm{B} \rightarrow \mathrm{A})$. The latter findings provide experimental evidence for the clinical observation that GERD patients complicated with BE have a significant increase in bile salt regurgitation. ${ }^{2}$ Taken together, the above findings suggest that in vivo bile salt exposure, accompanied by acid, has more injurious effect. In cell-culture experiments, discontinuation of the treatment with acid and bile salt after 2 weeks, at which time maximum mAbDas1-positive cells were seen, caused regression of CEP. However, re-exposure to acid and bile salt promptly initiated induction of CEP expression within 5 days, much earlier than the cells which are exposed to acid and bile for the first time (unpublished data). This may provide additional experimental evidence for the necessity of continued acid suppression. Patients with dysplastic BE are reported to show a reversal of the dysplastic process by proton pump inhibitor therapy; ${ }^{66-68}$ however, it is unknown if the lesions will reoccur once such a treatment is stopped.

The BAR-T cell line is reported to be a heterogeneous mix of cells of different phenotypes ${ }^{52}$ and/or cells in different stages of differentiation. We observed an increase in CK8/18 expression in the BAR-T cell line significantly in response to bile at $\mathrm{pH} 4$, as compared to acid alone or bile salt at neutral $\mathrm{pH}$. The cytokeratins comprise the intermediate filament network considered as a rather static structure responsible for mechanical stability of cells. However, the importance of $\mathrm{CK} 8 / 18$ in the maintenance of non-mechanical functions, such as functional integrity of cells and defense against toxic injury as in chronic cholestasis reflecting a cellular stress response, has been reported in a mouse model of liver injury. ${ }^{69,70}$ Upregulation of $\mathrm{CK} 8 / 18$ protein in our experimental model indicates the possibility of a similar protective phenomenon in the Barrett's esophageal cells in response to acid- and bile-induced toxicity. Further investigation of the correlation between CK8/18 upregulation and esophageal injury may explain the appearance of columnar metaplasia at the distal esophagus, as observed in $\mathrm{BE}$.

Colocalization of CK8/18 and CEP indicated that the majority of the columnar cells were of colonic phenotype. However, after treatment, particularly with bile at $\mathrm{pH} 4$, the number of cells expressing colonic phenotype was higher than that expressing CK8/18 phenotype, indicating the expression of CEP in the small percentage of cells that were negative for CK8/18 as well as CK4. It is unknown if these 
CK8/18-negative but CEP-positive cells arose from progenitors as result of acid and bile salt treatment. Similar colocalization studies could not be performed with p75NTRpositive population due to very small number of such cells. Further enrichment of p75NTR progenitors is necessary to conclusively assess the contribution of these cells toward differentiation of any specific phenotype. The reactivity of mAbDas-1 against hepatic progenitor cells has been reported by us, earlier. ${ }^{71}$ In this study, we also demonstrated that fetal esophageal mucosa reacts with mAbDas- 1 but not with adult esophagus. Thus, presence of mAbDas- 1 reactivity in fetal esophageal mucosa, followed by its loss in the normal adult esophagus and reappearance of activity in $\mathrm{BE}$ as well as in esophageal adenocarcinoma may provide an important clue concerning the lineage analysis of $\mathrm{BE} .{ }^{71} \mathrm{~A}$ future study, using P75NTR-enriched cell population, following their differentiation in response to acid and or bile, may provide important information regarding the origin of $\mathrm{BE}$.

We observed induction of Cox-2 expression in our study both in the colonic/columnar and in the non-colonic/noncolumnar cell populations of unknown phenotype in response to acid and/or bile treatment/s. There was, however, no significant induction of the CK4 cell phenotype with any of the treatments. Cox-2 upregulation, in response to acute acid and bile salt treatment, has been reported in normal esophagus, ${ }^{24} \mathrm{BE},{ }^{20}$ as well as in esophageal adenocarcinoma cells. ${ }^{21}$ Cox-2 suppression therapy has been suggested for better prognostic outcomes in Barrett's carcinomas. ${ }^{43}$ Upregulation of Cox-2 has been associated with increased proliferation mediated by activation of MAPK pathways, due to acid and bile salt exposure in SEG-1 cells. ${ }^{22,23}$ Such proliferation was not seen in the non-neoplastic BAR-T cells. These differences may be due to difference in cell lines used in the experiments (cancer cell line SEG-1 vs benign Barrett's cells) or due to the use of regular $5 \%$ serum-substituted media in our experiments to maintain long-term cultures $v s$ serum-deprived cells used by others investigators for onetime treatment.

In summary, using a non-neoplastic Barrett's cell line (BAR-T), which is composed of both squamous (CK4) and metaplastic/columnar cells (villin- and alcian blue-positive), ${ }^{52}$ we demonstrate selective increase of CK8/18 type columnar cells, colonic phenotype (mAbDas-1-positive) and Cox-2 expression following chronic (up to 6 weeks) repeated exposure to acid and bile salt. Bile and acid together $(\mathrm{A}+\mathrm{B}$ $\mathrm{pH}$ 4) were found to be more potent than either alone. However, acid exposure alone, immediately following bile priming, was also a potent stimulator of colonic phenotype. As mAbDas-1 reactivity has been shown to be strongly associated with precancerous conditions and adenocarcinomas of the esophagus, stomach and small intestine, induction of this phenotype in the Barrett's cell line may provide an experimental model for further understanding of the pathogenesis of Barrett's metaplasia $\rightarrow$ dysplasia $\rightarrow$ esophageal adenocarcinoma.
ACKNOWLEDGEMENT

The work is supported, in part, by a research Grant no. RO1DK063618 from the NIDDK-NIH.

1. Buskens CJ, Hulscher JB, van Gulik TM, et al. Histopathologic evaluation of an animal model for Barrett's esophagus and adenocarcinoma of the distal esophagus. J Surg Res 2006;135:337-344.

2. Richter JE. Importance of bile reflux in Barrett's esophagus. Dig Dis 2000;18:208-216.

3. Sato T, Miwa K, Sahara H, et al. The sequential model of Barrett's esophagus and adenocarcinoma induced by duodeno-esophageal reflux without exogenous carcinogens. Anticancer Res 2002;22:39-44.

4. Kauer WK, Stein HJ. Bile reflux in the constellation of gastroesophageal reflux disease. Thorac Surg Clin 2005;15:335-340.

5. Lagergren J. Oesophageal cancer and gastro-oesophageal reflux: what is the relationship? Gut 2004;53:1064-1065.

6. Lagergren J, Bergstrom R, Lindgren A, et al. Symptomatic gastroesophageal reflux as a risk factor for esophageal adenocarcinoma. N Engl J Med 1999;340:825-831.

7. Solaymani-Dodaran M, Logan RF, West J, et al. Risk of oesophageal cancer in Barrett's oesophagus and gastro-oesophageal reflux. Gut 2004;53:1070-1074.

8. Cameron AJ, Ott BJ, Payne WS. The incidence of adenocarcinoma in columnar-lined (Barrett's) esophagus. N Engl J Med 1985;313:857-859.

9. Menke-Pluymers MB, Hop WC, Dees J, et al. Risk factors for the development of an adenocarcinoma in columnar-lined (Barrett) esophagus. The Rotterdam Esophageal Tumor Study Group. Cancer 1993;72:1155-1158.

10. Attwood SE, Smyrk TC, DeMeester TR, et al. Duodenoesophageal reflux and the development of esophageal adenocarcinoma in rats. Surgery 1992;111:503-510.

11. Fein $\mathrm{M}$, Fuchs $\mathrm{KH}$, Stopper $\mathrm{H}$, et al. Duodenogastric reflux and foregut carcinogenesis: analysis of duodenal juice in a rodent model of cancer. Carcinogenesis 2000;21:2079-2084.

12. Gillen $P$, Keeling $P$, Byrne PJ, et al. Implication of duodenogastric reflux in the pathogenesis of Barrett's oesophagus. Br J Surg 1988;75:540-543.

13. Gillen $\mathrm{P}$, Keeling $\mathrm{P}$, Byrne PJ, et al. Experimental columnar metaplasia in the canine oesophagus. Br J Surg 1988;75:113-115.

14. Orlando RC. Mechanisms of epithelial injury and inflammation in gastrointestinal diseases. Rev Gastroenterol Disord 2002;2(Suppl 2):S2-S8.

15. Kumagai $H$, Mukaisho $K$, Sugihara $H$, et al. Cell kinetic study on histogenesis of Barrett's esophagus using rat reflux model. Scand J Gastroenterol 2003;38:687-692.

16. Mandys V, Lukas K, Revoltella R. Different patterns of cytokeratin expression in Barrett's esophagus-what is beyond? Pathol Res Pract 2003;199:581-587.

17. Sawhney RA, Shields HM, Allan $\mathrm{CH}$, et al. Morphological characterization of the squamocolumnar ction of the esophagus in patients with and without Barrett's epithelium. Dig Dis Sci 1996;41:1088-1098.

18. Casson AG. Role of molecular biology in the follow-up of patients who have Barrett's esophagus. Chest Surg Clin N Am 2002;12:93-111, ix-x.

19. Nehra D, Howell $P$, Williams $C P$, et al. Toxic bile acids in gastrooesophageal reflux disease: influence of gastric acidity. Gut 1999:44:598-602.

20. Jaiswal K, Lopez-Guzman C, Souza RF, et al. Bile salt exposure increases proliferation through p38 and ERK MAPK pathways in a non-neoplastic Barrett's cell line. Am J Physiol Gastrointest Liver Physiol 2006;290:G335-G342.

21. Jaiswal K, Tello V, Lopez-Guzman C, et al. Bile salt exposure causes phosphatidyl-inositol-3-kinase-mediated proliferation in a Barrett's adenocarcinoma cell line. Surgery 2004;136:160-168.

22. Souza RF, Shewmake K, Pearson S, et al. Acid increases proliferation via ERK and p38 MAPK-mediated increases in cyclooxygenase-2 in Barrett's adenocarcinoma cells. Am J Physiol Gastrointest Liver Physiol 2004;287:G743-G748.

23. Souza RF, Shewmake K, Terada LS, et al. Acid exposure activates the mitogen-activated protein kinase pathways in Barrett's esophagus. Gastroenterology 2002;122:299-307.

24. Jiang ZR, Gong J, Zhang ZN, et al. Influence of acid and bile acid on ERK activity, PPARgamma expression and cell proliferation in normal 
human esophageal epithelial cells. World J Gastroenterol 2006;12:2445-2449.

25. Debruyne PR, Witek M, Gong L, et al. Bile acids induce ectopic expression of intestinal guanylyl cyclase $C$ Through nuclear factorkappaB and Cdx2 in human esophageal cells. Gastroenterology 2006;130:1191-1206.

26. Kazumori $\mathrm{H}$, Ishihara $\mathrm{S}$, Rumi MA, et al. Bile acids directly ment caudal related homeobox gene $\mathrm{Cdx} 2$ expression in oesophageal keratinocytes in Barrett's epithelium. Gut 2006;55:16-25.

27. Fitzgerald RC, Oy MB, Triadafilopoulos G. Dynamic effects of acid on Barrett's esophagus. An ex vivo proliferation and differentiation model. J Clin Invest 1996:98:2120-2128.

28. Jolly AJ, Wild CP, Hardie LJ. Acid and bile salts induce DNA damage in human oesophageal cell lines. Mutagenesis 2004;19:319-324.

29. Das KM, Sakamaki S, Vecchi M, et al. The production and characterization of monoclonal antibodies to a human colonic antigen associated with ulcerative colitis: cellular localization of the antigen by using the monoclonal antibody. J Immunol 1987;139:77-84.

30. Halstensen TS, Das KM, Brandtzaeg P. Epithelial deposits of immunoglobulin $\mathrm{G} 1$ and activated complement colocalise with the $\mathrm{M}(\mathrm{r})$ 40 kD putative autoantigen in ulcerative colitis. Gut 1993;34:650-657.

31. Kesari KV, Yoshizaki N, Geng X, et al. Externalization of tropomyosin isoform 5 in colon epithelial cells. Clin Exp Immunol 1999;118:219-227.

32. Das KM, Prasad I, Garla S, et al. Detection of a shared colon epithelial epitope on Barrett epithelium by a novel monoclonal antibody. Ann Intern Med 1994;120:753-756.

33. Fisher RS, Bromer MQ, Thomas RM, et al. Predictors of recurrent specialized intestinal metaplasia after complete laser ablation. Am J Gastroenterol 2003;98:1945-1951.

34. Glickman JN, Wang H, Das KM, et al. Phenotype of Barrett's esophagus and intestinal metaplasia of the distal esophagus and gastroesophageal junction: an immunohistochemical study of cytokeratins 7 and 20, Das-1 and $45 \mathrm{Ml}$. Am J Surg Pathol 2001;25:87-94.

35. Griffel LH, Amenta PS, Das KM. Use of a novel monoclonal antibody in diagnosis of Barrett's esophagus. Dig Dis Sci 2000;45:40-48.

36. Piazuelo MB, Haque $S$, Delgado $A$, et al. Phenotypic differences between esophageal and gastric intestinal metaplasia. Mod Pathol 2004;17:62-74.

37. Rogge-Wolf $C$, Seldenrijk CA, Das KM, et al. Prevalence of mabDAS-1 positivity in biopsy specimens from the esophagogastric junction. Am J Gastroenterol 2002;97:2979-2985.

38. Su Y, Chen X, Klein M, et al. Phenotype of columnar-lined esophagus in rats with esophagogastroduodenal anastomosis: similarity to human Barrett's esophagus. Lab Invest 2004;84:753-765.

39. DeMeester SR, Wickramasinghe KS, Lord RV, et al. Cytokeratin and DAS-1 immunostaining reveal similarities among cardiac mucosa, CIM and Barrett's esophagus. Am J Gastroenterol 2002;97:2514-2523.

40. Jang TJ, Cho MY. Cyclooxygenase-2 expression and cell proliferation are increased in MUC2-positive area of columnar-lined esophagus. Pathol Int 2005;55:546-549.

41. Abdalla SI, Sanderson IR, Fitzgerald RC. Effect of inflammation on cyclooxygenase (COX)-2 expression in benign and malignant oesophageal cells. Carcinogenesis 2005;26:1627-1633.

42. Buskens CJ, Sivula A, van Rees BP, et al. Comparison of cyclooxygenase 2 expression in adenocarcinomas of the gastric cardia and distal oesophagus. Gut 2003;52:1678-1683.

43. Mobius C, Stein HJ, Spiess C, et al. COX2 expression, angiogenesis, proliferation and survival in Barrett's cancer. Eur J Surg Oncol 2005:31:755-759.

44. Piazuelo E, Jimenez P, Lanas A. COX-2 inhibition in esophagitis, Barrett's esophagus and esophageal cancer. Curr Pharm Des 2003;9:2267-2280.

45. Kleeff J, Friess $\mathrm{H}$, Liao $\mathrm{Q}$, et al. Immunohistochemical presentation in non-malignant and malignant Barrett's epithelium. Dis Esophagus 2002;15:10-15.

46. Bennett A, Civier A, Hensby $\mathrm{CN}$, et al. Measurement of arachidonate and its metabolites extracted from human normal and malignant gastrointestinal tissues. Gut 1987;28:315-318.

47. Kargman SL, O'Neill GP, Vickers PJ, et al. Expression of prostaglandin $\mathrm{G} / \mathrm{H}$ synthase-1 and -2 protein in human colon cancer. Cancer Res $1995 ; 55: 2556-2559$
48. Kutchera $\mathrm{W}$, Jones $\mathrm{DA}$, Matsunami $\mathrm{N}$, et al. Prostaglandin $\mathrm{H}$ synthase 2 is expressed abnormally in human colon cancer: evidence for a transcriptional effect. Proc Natl Acad Sci USA 1996;93:4816-4820.

49. Ristimaki $\mathrm{A}$, Honkanen $\mathrm{N}$, kala $\mathrm{H}$, et al. Expression of cyclooxygenase-2 in human gastric carcinoma. Cancer Res 1997:57:1276-1280.

50. Xu XC, Lee JS, Lippman SM, et al. Increased expression of cytokeratins CK8 and CK19 is associated with head and neck carcinogenesis. Canc Epidemiol Biomarkers Prev 1995;4:871-876.

51. Boch JA, Shields HM, Antonioli DA, et al. Distribution of cytokeratin kers in Barrett's specialized columnar epithelium. Gastroenterology 1997;112:760-765.

52. Jaiswal KR, Morales CP, Feagins LA, et al. Characterization of telomerase-immortalized, non-neoplastic, human Barrett's cell line (BAR-T). Dis Esophagus 2007:20:256-264.

53. Okumura $T$, Shimada $Y$, Imamura $M$, et al. Neurotrophin receptor p75(NTR) characterizes human esophageal keratinocyte stem cells in vitro. Oncogene 2003;22:4017-4026.

54. Wallace AS, Burns AJ. Development of the enteric nervous system, smooth muscle and interstitial cells of Cajal in the human gastrointestinal tract. Cell Tissue Res 2005;319:367-382.

55. Overton WR. Modified histogram subtraction technique for analysis of flow cytometry data. Cytometry 1988;9:619-626.

56. Geng X, Biancone L, Dai HH, et al. Tropomyosin isoforms in intestinal mucosa: production of autoantibodies to tropomyosin isoforms in ulcerative colitis. Gastroenterology 1998;114:912-922.

57. Filipe Ml, Osborn $\mathrm{M}$, Linehan J, et al. Expression of transforming growth factor alpha, epidermal growth factor receptor and epidermal growth factor in precursor lesions to gastric carcinoma. Br J Cancer 1995;71:30-36.

58. Jass JR, Filipe MI. The mucin profiles of normal gastric mucosa, intestinal metaplasia and its variants and gastric carcinoma. Histochem J 1981;13:931-939.

59. Matsukura N, Suzuki K, Kawachi T, et al. Distribution of ker enzymes and mucin in intestinal metaplasia in human stomach and relation to complete and incomplete types of intestinal metaplasia to minute gastric carcinomas. J Natl Cancer Inst 1980;65:231-240.

60. Stemmermann GN. Intestinal metaplasia of the stomach. A status report. Cancer 1994;74:556-564.

61. Blok P, Craanen ME, Offerhaus GJ, et al. Gastric carcinoma: clinical, pathogenic, and molecular aspects. QJM 1997;90:735-749.

62. Mirza ZK, Das KK, Slate J, et al. Gastric intestinal metaplasia as detected by a monoclonal antibody is highly associated with gastric adenocarcinoma. Gut 2003;52:807-812.

63. Onuma EK, Amenta PS, Jukkola AF, et al. A phenotypic change of small intestinal epithelium to colonocytes in small intestinal adenomas and adenocarcinomas. Am J Gastroenterol 2001;96:2480-2485.

64. Pantuck AJ, Bancila E, Das KM, et al. Adenocarcinoma of the urachus and bladder expresses a unique colonic epithelial epitope: an immunohistochemical study. J Urol 1997;158:1722-1727.

65. Pantuck AJ, Murphy DP, Amenta PS, et al. The monoclonal antibody $7 \mathrm{E} 12 \mathrm{H} 12$ can differentiate priy adenocarcinoma of the bladder and prostate. Br J Urol 1998;82:426-430.

66. Hillman LC, Chiragakis L, Shadbolt B, et al. Proton-pump inhibitor therapy and the development of dysplasia in patients with Barrett's oesophagus. Med J Aust 2004;180:387-391.

67. Hillman LC, Chiragakis L, Shadbolt B, et al. Effect of proton pump inhibitors on kers of risk for high grade dysplasia and oesophageal cancer in Barrett's oesophagus. Aliment Pharmacol Ther 2008;27: 321-326.

68. El-Serag HB, Aguirre TV, Davis S, et al. Proton pump inhibitors are associated with reduced incidence of dysplasia in Barrett's esophagus. Am J Gastroenterol 2004;99:1877-1883.

69. Fickert $P$, Trauner $M$, Fuchsbichler $A$, et al. Cytokeratins as targets for bile acid-induced toxicity. Am J Pathol 2002;160:491-499.

70. Ku NO, Michie SA, Soetikno RM, et al. Susceptibility to hepatotoxicity in transgenic mice that express a dominant-negative human keratin 18 mutant. J Clin Invest 1996;98:1034-1046.

71. Badve $S$, Logdberg $L$, Sokhi $R$, et al. An antigen reacting with das-1 monoclonal antibody is ontogenically regulated in diverse organs including liver and indicates sharing of developmental mechanism among cell lineages. Pathobiology 2000;68:76-86. 